\title{
防排煙時の室間圧力差予測のための中間的開放扉の基本特性 \\ BASIC PROPERTIES OF INTERMEDIATE OPEN DOORS FOR PREDICTING PRESSURE DIFFERENCES BETWEEN ROOMS DURING A SMOKE CONTROL
}

\author{
広田正之*1,*2, 松山賢*3, 山名俊男*4, 若松孝旺*5 \\ Masayuki HIROTA, Ken MATSUYAMA, Toshio YAMANA \\ and Takao WAKAMATSU
}

\begin{abstract}
The basic properties of intermediate open doors necessary for predicting pressure differences between rooms in a smoke control plan were determined. These were determined in the following manner. (1) An experimental system was proposed for determining the flow rate coefficient relative to the opening angle of an intermediate open door. (2) The relationship of door closing force, door shape and pressure difference between rooms with respect to the opening angle of a free-swinging door was proposed by introducing a pressure difference distribution coefficient. (3) The relationship between the opening angle of an arbitrary free-swinging door and the average pressure difference between rooms can be estimated from the door width and height by determining this relationship for a specific door. (4) The pressure difference between rooms immediately before opening a door can be estimated from the door surface area on which pressure is acting and the door closing force regardless of the magnitude of the door closing force.
\end{abstract}

\author{
Keywords : Intermediate Open Door, Door Opening Angle, Flow Rate Coefficient, Pressure Difference Distribution Coefficient, \\ Pressure Difference between Rooms \\ 中間的開放屝、覀開放角度、流量係数、圧力差分布係数、室間圧力差
}

\section{1. はじめに}

避難安全をはじめ消防活動に幅広く関わる扉開放条件は、室間圧 力差を利用した煙制御を計画する上で支配的な要素である。これま で、屝の開閉については閉鎖か全開かの設定が主に行われてきた。 閉鎖でも全開でもない、その中間の開放状態（以下、中間的開放と いう）にあたる設定は計画で殆どなかった。しかし、建築基準法に よる性能規定化が進み、消防法による性能規定化も推進される中、 煙制御計画における幅広い火災シナリオに対応していくためには、 中間的開放時の扉の基本特性が重要となってきた。

防火扉は、火災時に自動閉鎖し、防火防煙区画を形成し、煙伝播 を抑制す、るしかし、防火屝の設置場所によっては、閉鎖障害や経 年劣化等による閉鎖性の低下により、火災時に閉鎖できない可能性 が危惧される。この様な閉鎖不成立による防火扉の開放開度を考虑 できる検討は、避難安全性の高い建物の赛現にとって重要である。

また、消防隊は、火点に向けて進入し、消火活動を行う。この場 合、活動拠点の防火扉は、通過に必要な幅を開放することになる。 階段室の防火扉も消防ホース分を少なくとも開放し、ホースを通す ようなことが考えられる。こうした消防活動に伴う防火扉の開放状 態も考虑し、消防活動の安全性を検討することが必要である。

一方、防火屝を挟む室間の圧力差によって防火屝が微少角度で開
放する危険性も否定できない。火災圧や加圧防煙の圧力が防火扉の 仕様によっては屝閉銧に支障をきたすことになる。特に、設計意匠 上、くぐり戸のようなラッチの無い防火屝が多くなり、圧力差に逆 らって閉鎖の難しい屝が増加している。屝の大型化もあり、圧力差 によってより大きな開放力が虑に作用し、開きやすい傾向にある。 圧力差によって、覀が開放する限界や中間的開放にある扉が煙伝播 に及ぼす影響をもとに、計画を見直せることが重要である。

以上のことから、本研究は、室間圧力差による煙制御計画に関わ る中間的開放状態にある防火墀の基本特性を明らかにする。

\section{2. 既往の研究と研究目的}

喓制御計画時の室間圧力差の予測には式 (1) が適用されている。

$Q=\alpha A \sqrt{2 \rho \Delta P}$

式 (1) の $\alpha$ は流量係数である。扉全開時の流量係数として0.64〜

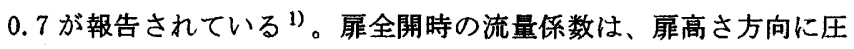
力差がない一様な場合 (以下、等圧という) 、及び屝高さ方向に圧 力差がある場合 ${ }^{1}$ （以下、不等庄という）に適用性が把握されてい る。屝閉鎖時の流量係数は実測による隙間相当開口面積刚えば2)を
*1 東京理科大学大学院 (博士後期課程)

*2 清水建設珠技術研究所 プロジェクトリーダー・工修

*3 東京理科大学火災科学研究センター 講師・博士 (工学)

*4 国土交通省国土技術政策総合研究所 主任研究官

*5 東京理科大学火災科学研究センター 教授. 工博
Graduate School of Science and Technology, Tokyo University of Science Project Leader, Institute of Technology, Shimizu Corporation, M. Eng. Lecturer, Center for Fire Science and Technology, Tokyo University of Science, Dr. Eng.

Senior Researcher, National Institute for Land and Infrastructure Management Prof., Center for Fire Science and Technology, Tokyo University of Science, Dr. Eng. 
基に単位面積あるいは単位長さ当たりの值に整理され、適用されて いる。しかし、中間的開放扉の流量係数は明らかにされていない。 なお、式 (1) の $\Delta P$ は、等圧の場合に、室間圧力差に相当する。不 等圧の場合に、式 (1) の $\Delta P$ は平均圧力差 ${ }^{3)}$ を示すことになるが、 以下の $\Delta P$ は高さ方向の室間圧力差の平均とし、両者は異なる。

扉開放角度に対する流量係数の值が明らかになると、扉の回転が 固定されている中間的開放屝の場合、これまでのようにして室間圧 力差を算定できる。すなわち、罪開放角度を決め、流量係数を求め て、室内圧力を仮定し、保存関係から室内圧力を修正する。

一方、扉の回転が固定されていないと、室間圧力差によっては看 が開放するため、室間圧力差に対する扉開放角度の大きさが適当か 否かを室内圧力とあわせて検討することになる。屝開放角度が当初 の設定と異なる場合には扉開放角度を修正する。山名 ${ }^{4)}$ は、付室に 給気し、階段室の防火覀の開放状態と給気量及び付室階段室間の圧 力差について実測を行った。しかし、郝開放角度の見直しが可能な 室間圧力差や扉閉鎖力等を考慮した関保は明らかにされていない。

以上のことから、本研究では、性能的防煙設計に凟するために、 室間圧力差を利用した煙制御計画に関わる中間的開放扉について基 本特性を捉えることを目的とする。以下の点を明らかにする。

・扉開放角度に対する流量倸数

・回転を固定していない扉の挙動のモデル化

・不等圧における扉举動モデルの適用性

・赫開放開始の要因

なお、中閒的開放屝の流量係数について、消防隊活動を対象に $0^{\circ}$ 〜 60 の開放範囲で阿部ら ${ }^{5)}$ によっても検討されているが、本研究 は、韮の開放篹囲を $0^{\circ} \sim 90^{\circ}$ までとり、さらに開放角度の大きさ をより細かく設定し、実験式を求めようとした点で異なる注)。

\section{3. 実験概要}

\section{1 実験装置}

\subsection{1防火丽}

防火扉の断面を図 1 に、立面を図 2 に示す。防火屝は、屝本体、 内枠、外枠の大きく3つの部位から構成されている。郝幅は片側で $0.8 \mathrm{~m}$ 、扉高さは2.581mである。主に扉上端と内枠間、扉下端と床面 との間に数mmの隙閒がある。これら以外に隙間は殆どみられない。

罪の閉鎖力は、バネの巻数を選択することによって、既存の閉鎖 力を広くカバーできるように12段階の調整を可能とした。郝開閉時 の举動を確認すると、扉の前後に圧力差がない状態でも、バネ巻数 4 以下は、扉の全閉までに時間を要した。このため、バネ巻数が 4 以下の閧鎖力は、室間圧力差による煙制御に適用が難しいと判断し た。従って、バネ巻数が $5 \sim 12$ の 8 段階を実験では对象とした。

\section{1 .2 実験施設}

寨験は、旧建設省建築研究所の実大火災実験棟で実施した。施設 概要を図 3 に示す。施設は、廊下 1 、廊下 2 (燃焼空閒)、排煙空間 を中心に、前室 1、エレベーターホール、計測空間から主に構成さ

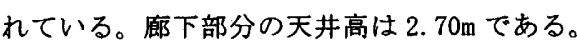

廊下 1 と燃焼空間の境界部分に防火扉を設置した。排煙空間には 排煙口がある。ここで機械排煙を行い、覀前後に室間圧力差を生じ させる。インバーターによるファン回転数で排煙風量を制御する。
ファン回転数と常温時の排気風量の関係を図 5 に示す。回転数と排 気風量はほぼ比例関係にある。前室 1 と廊下 1 の間、燃焼空間と排 煙空間の間に開口部があり、排煙ファン稼働時の主な流路となる。 空間の迴りは目張りをした。リーク経路は、図3の出入口及び床 面に接して壁に設けた計測コード類を通す計測用開口に限定した。

\subsection{3 罪開度測定装置}

㗺開放による開放角度は、微少角度まで把握するために、罪開放 開度をデジタル値に変換できる角度センサーを設け、記録した。

角度センサーはブリッジ回路を中心に構成されている。角度セン サーには、アームを 2 箇所取り付けている。屝回転角度が扉開放開 度となるように、開閉する屝と枠にアームを固定した（図1）。

\section{2 実験方法}

\subsection{1 実験タイプと実験ケース}

実験は 4 つのタイプに分け、タイプ毎の実験ケースで実施した。 実験ケースを表 1 に示す。防火扉 $A 、 B$ 中、開放に関与しない方 の扉は、あらかじめ閉鎖し、固定した。

実験タイプ 1 は、防火裶のバネ巻数に忘じた扉閉鎖力を捉えるた めに扉開放角度、集中荷重を計測した。ケース毎にバネ巻数をパラ メータに、扉 $B$ の開放角度を変えた。開放した扉 $B$ を動かない様に 固定し、所定の位置にロードセルを品面に垂直に設置した。覀 $B$ の 固定を解除してもロードセルが動かないことを確認し、計測した。

実験タイプ 2 は、中間的開放扉の開放角度に対し、流量係数、蜉 前後の圧力差分布を明らかにする実験である。扉開放角度、室間圧 力差と扉前後圧力差、空間温度、排気風量を主に計測した。扉の開 放方向と苝通過気流の流れが同方向での流量保数、併せて扉前後の 圧力差分布を求める各ケースは、郝 $B$ を対象とし、開放角度をパラ メータとした。また、丞の開放方向と郝通過気流の流れが逆方向の 場合に流量係数を求めるケースでは、秒 $A$ を対象とした。対象とし た郝の開放角度を設定した後に、その郝の回転も固定した。機械排 煙ファンの回転数を制御し、屝通過風量はケース毎に変えた。

実験タイプ 3 では、室間圧力差により、屝が開放する直前および 㗺が少ない角度で開放した段階での扉開放角度・郝閉鎖力・室間圧 力差の関係を明らかにするために、屝開放角度、室閒圧力差、空間 温度、排気風量を主に計測した。韭 $B$ の閉鎖力をパラメータとし、 扉通過風量もケース毎に変えた。悲 $B$ の回転は自由である。

実験タイプ 4 は、タイプ 3 で明らかにする少ない角度で開放させ た屝の举動を支配する関倸式が屝前後に温度差がある不等圧の場合 に適用可能か否かを確認する実験である。扉開放角度、室間圧力差 空間温度、排煙風量の計測を主に行った。メタノール $\left(0.375 \mathrm{~m}^{2}\right)$ を 燃焼させ、扉前後に温度差をつくる。扉 $B$ の回転は固定しない。ケ 一ス毎に、屝 $B$ の閉鎖力と扉通過風量も変えて実施した。

また、燃焼空間と排煙空間迴り、防火扉の各部位のリーク量を把 握する実測を行った。寒測ケースを、対象部位別に表 2 に示す。対 象部位はシールで各々目張りした。ケース毎に、目張りを外し、機 械排煙ファンの回転数を变化させ、実測した。排煙空間および燃焼 空間の周囲の空間は、開口部を開放し、外気同等とした。

\subsection{2 計測項目および計測方法}


主な計測点の位置を図 3 に示す。計測項目は、呇閉鎖力、屝開放 角度、ダクト内流速、室間圧力差、空間及び開口部の温度である。

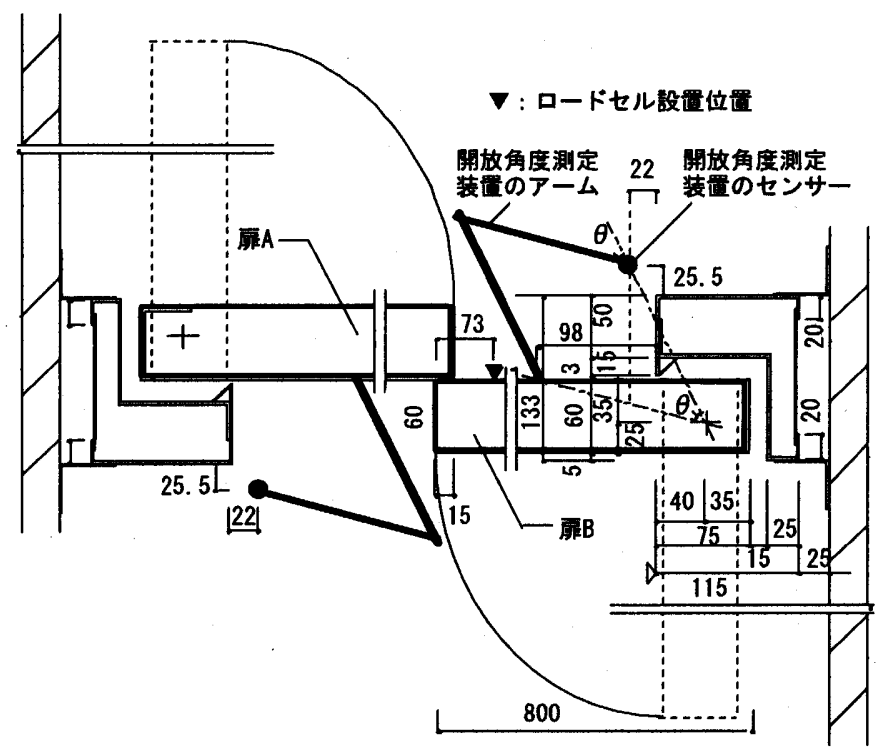

図 1 防火罪の概要 (平面図)

(単位 $\mathrm{mm}$ )

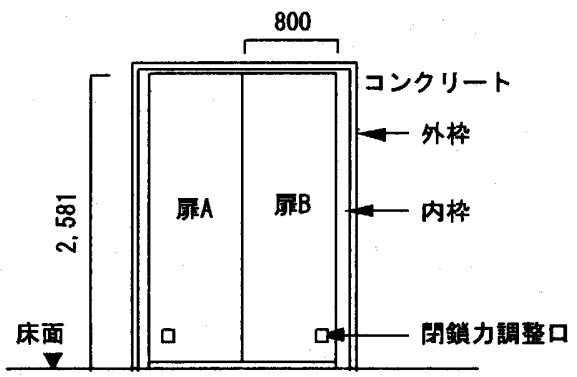

図 2 防火扉の概要（立面図）

(単位 $\mathrm{mm}$ )

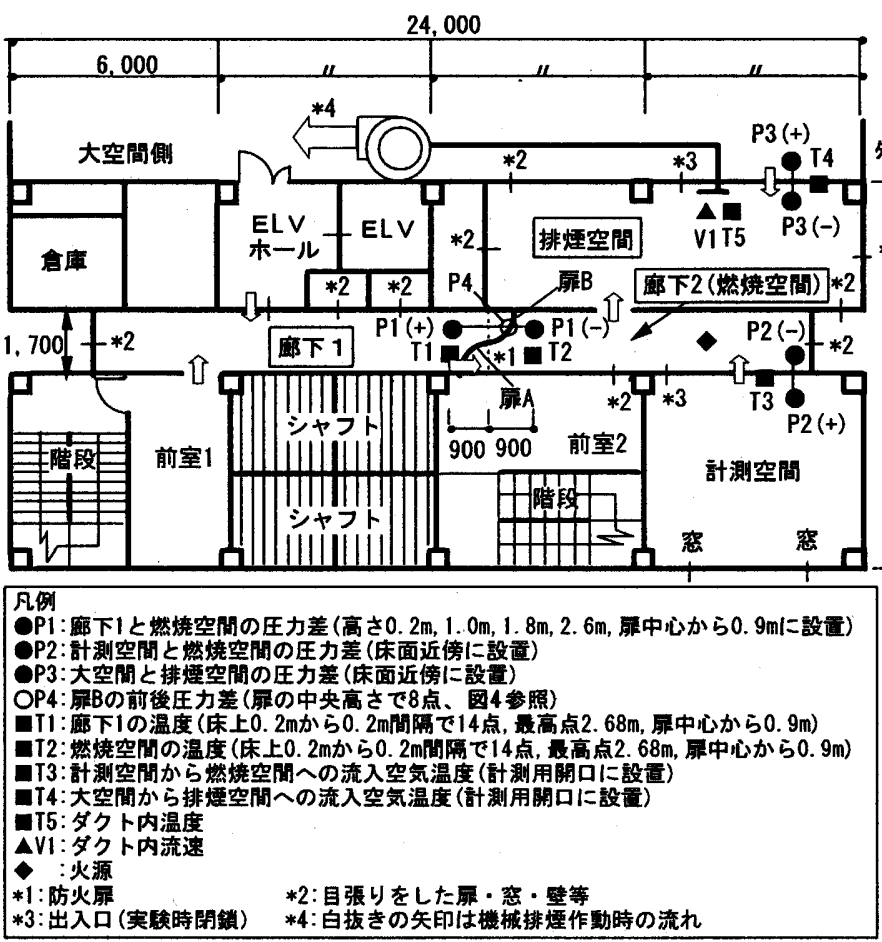

図 3 実験施設概要と計測点

(単位 $\mathrm{mm}$ )

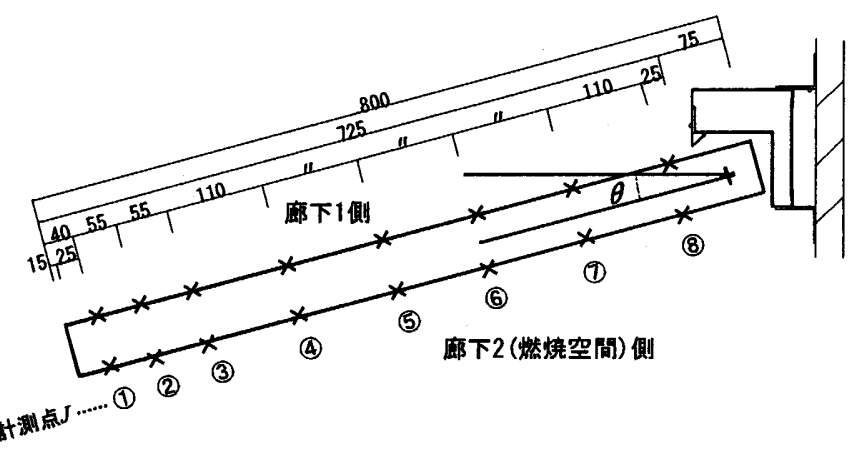

図 4 扉 $B$ 前後の圧力差分布の計測点 $J(\mathrm{P} 4)$

(単位 mm)

表 $1 \mathrm{a}$ 実験ケース（実験タイプ1）

\begin{tabular}{|c|c|c|c|c|c|c|c|c|}
\hline 实旗ヶース & $1-1$ & $1-2$ & $1-3$ & $1-4$ & $1-5$ & $1-6$ & $1-7$ & $1-8$ \\
\hline バネ卷数 & 5.0 & 6.0 & 7.0 & 8.0 & 9.0 & 10.0 & 11.0 & 12.0 \\
\hline 显開放角度 $\left[^{\circ}\right]$ & $1.5^{\circ}$ & $-15^{\circ}$ & 下त्1 & & & & カ゚ピッチ & 設定 \\
\hline 星回転 & \multirow{2}{*}{\multicolumn{8}{|c|}{ 固定 }} \\
\hline ファン回転数 [HZ] & & & & & & & & \\
\hline 然焼 & \\
\hline
\end{tabular}

表 $1 b$ 実験ケース（実験タイプ2）

\begin{tabular}{|c|c|}
\hline 实炴ヶース & \begin{tabular}{|l|l|l|l|l|l|l|}
$2-1^{* 1}$ & $2-2^{* 2}$ & $2-3^{* 3}$ & $2-4^{* 2}$ & $2-5^{* 3}$ & $2-6^{* 2}$ & $2-7^{* 3}$ \\
\end{tabular} \\
\hline バネ淃数 & \\
\hline 严開度角度 & \begin{tabular}{|l|l|l|}
3.0 & 4.5 & 6.0 \\
\end{tabular} \\
\hline 显回宣 & 固定 \\
\hline 7フン回藏数[HZ2 & $\begin{array}{l}0 \sim 30|10 \sim 40| 10 \sim 55 \mid \\
\end{array}$ \\
\hline 怒烧 & - \\
\hline 英鞅ヶース & \begin{tabular}{l|l|l|l|l|l|l|l|l}
$2-9^{* 3}$ & $2-10^{* 2}$ & $2-11^{* 2}$ & $2-12^{* 3}$ & $2-13^{* 3}$ & $2-14^{* 3}$ & $2-15^{* 2}$ & $2-16^{* 3}$ \\
\end{tabular} \\
\hline 八゙ネ巷数 & \\
\hline 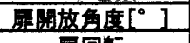 & \begin{tabular}{|l|l|l|l|l|l|l|l|}
12.0 & 13.5 & 15.0 & 18.0 & 24.0 & 30.0 & 36.0 & 42.0 \\
\end{tabular} \\
\hline 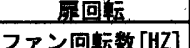 & $\begin{array}{c}\text { 固定 } \\
10 \sim 60\end{array}$ \\
\hline 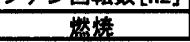 & 無し \\
\hline 荚騃ヶース & \begin{tabular}{|l|l|l|l|l|l|l|l}
$2-17^{* 2}$ & $2-18^{* 3}$ & $2-19^{* 2}$ & $2-20^{* 3}$ & $2-21^{* 2}$ & $2-22^{* 3}$ & $2-23^{* 2}$ & $2-24^{* 2}$ \\
\end{tabular} \\
\hline バネ数 & \\
\hline 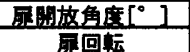 & \begin{tabular}{l|l|l|l|l|l|}
48.0 & 54.0 & 60.0 & 66.0 & 72.0 & 78.0 \\
\end{tabular} \\
\hline ファン回枟数 [HZ] & $25 \sim 60$ \\
\hline & \\
\hline
\end{tabular}

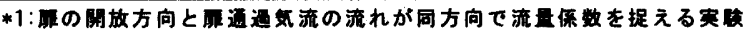

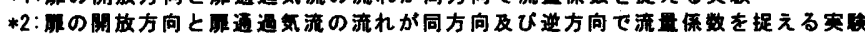

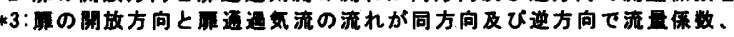

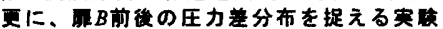

表 $1 \mathrm{c}$ 実験ケース（実験タイプ3）

\begin{tabular}{|c|c|c|c|c|c|c|c|c|}
\hline 实缋ケース & $3-1$ & $\overline{3-2}$ & $3-3$ & $3-4$ & $3-5$ & $3-6$ & $3-7$ & $3-8$ \\
\hline バネ数 & 5.0 & 6.0 & 7.0 & 8.0 & 9.0 & 10.0 & & 12.0 \\
\hline 显開放角度 $\left.0^{\circ}\right]$ & \multirow{2}{*}{\multicolumn{8}{|c|}{ 自由（固定なし） }} \\
\hline 翡回忶 & & & & & & & & \\
\hline ファン回転数 [HZ] & \multicolumn{8}{|c|}{$4 \sim 60$} \\
\hline 燃焼 & \multicolumn{8}{|c|}{$\begin{array}{l}4 \sim 60 \\
\text { 然L }\end{array}$} \\
\hline
\end{tabular}

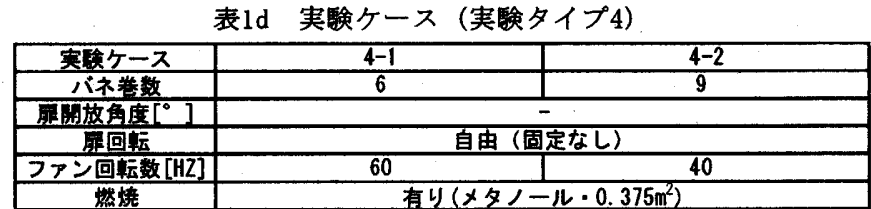

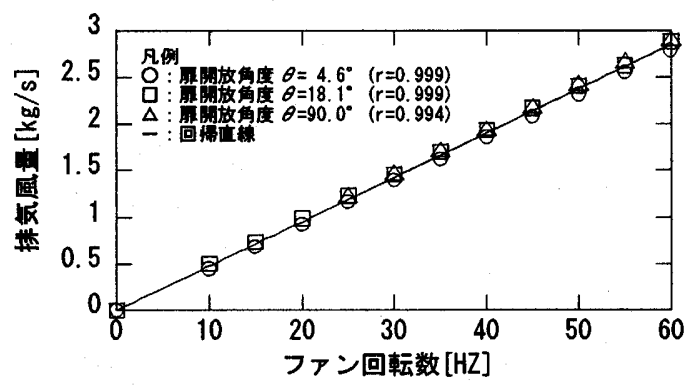

図 5 排煙ファン回転数と排気風量 
表 2 隙間の実測ケース

\begin{tabular}{|c|c|c|c|c|c|c|c|c|c|c|c|}
\hline \multirow{2}{*}{\multicolumn{2}{|c|}{ 対象部位 }} & \multicolumn{10}{|c|}{ 实测ケース } \\
\hline & & $T$ & 2 & 3 & 4 & 5 & 6 & 7 & 8 & 9 & 10 \\
\hline \multirow{4}{*}{ 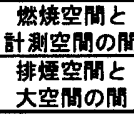 } & 罪(出入口) & \multirow{8}{*}{ 目張 } & 0 & 0 & 0 & 0 & 0 & 0 & 0 & 0 & 0 \\
\hline & 㖕测用關口 & & \multirow{7}{*}{ 目張 } & 0 & 0 & 0 & 0 & 0 & 0 & 0 & 0 \\
\hline & 曈测用關口 & & & \multirow{6}{*}{ 目張 } & 0 & 0 & 0 & 0 & 0 & 0 & 0 \\
\hline & 罪(出入口) & & & & \multirow{5}{*}{ 目張 } & 0 & 0 & 0 & 0 & 0 & 0 \\
\hline \multirow{4}{*}{ 防火暃 } & $\begin{array}{l}\text { 外枠とコン } \\
\text { クリート罗 }\end{array}$ & & & & & \multirow{4}{*}{ 目張 } & 0 & $\mathrm{O}$ & 0 & $\mathrm{O}$ & 0 \\
\hline & $\begin{array}{c}\text { 内枠・床 } \\
\text { と㺖成 }\end{array}$ & & & & & & \multirow{3}{*}{ 目镸 } & 0 & 0 & 0 & 0 \\
\hline & 内伜と外伜間 & & & & & & & \multirow[b]{2}{*}{ 目镸 } & 0 & 0 & 0 \\
\hline & 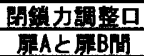 & & & & & & & & & $\frac{0}{123}$ & $\frac{0}{0}$ \\
\hline
\end{tabular}

表 3 主な部位の隙間相当開口面積

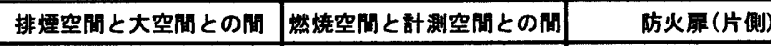

$0.010\left[\mathrm{~m}^{2}\right]$ $0.010\left[\mathrm{~m}^{2}\right]$ $0.012\left[\mathrm{~m}^{2}\right]$

覀閉鎖力 (1点) は、ロードセルにより所定の位罩で集中荷重を計 測した。屝の開放角度 (1点) は、開放角度の測定装置を防火㦄に設 置し、計測した。排煙ダクト内の流速 (1点) の計測は、ダクトに組 み込んだエアロダクトに微差圧計（岡野製作所製差圧計 DMP201N ・ レンジ $0 〜 200 \mathrm{~Pa} \cdot$ 精度士0.2\%FS）を設置して行った。防火扉を挟 む室閒圧力差 (4点) は、微差圧計 (Validyne 社製圧カトランスデュ ーサー DP45-14 ・レンジ $0 \sim 100 \mathrm{~Pa} \cdot$ 精度 $\pm 0.25 \% \mathrm{FS}$ ）、これ以外の 室間圧力差 (各 1 点) は、微差圧計（岡野製作所製 DMP201N ・レン ジ 0〜 200Pa ・精度士0.2\%FS) によって計測した。温度は、ダクト 内 (1点)、空間内 (各14点)、計測用開口部（各 1 点）で $T$ 型熱電 対 $(\phi 0.32 \mathrm{~mm})$ により計測した。

防火罪を挟む室閒圧力差の計測点は床上 $0.2 \mathrm{~m} 、 1.0 \mathrm{~m} 、 1.8 \mathrm{~m} 、 2.6 \mathrm{~m}$ の高さに設置した。廊下 1 と燃焼空間の垂直温度計測点は床上 $0.2 \mathrm{~m}$ から0.2m間隔で設けた。最高高さは $2.68 \mathrm{~m}$ とした。

計測間隔は 2 秒とした。計測時間は、バネ巻数および扉開放角度 （実験タイプ1）、扉開放角度および機械排煙ファン回転数（実験タ イプ2)、バネ巻数および排煙ファン回転数（実験タイプ3）を設定し 各実験ケースで 2 分間を基本とした。燃焼実験（実験タイプ4）は、 空間温度が上昇から下降に向かうまで継続して計測した。

これらの実験值は、計測時間内の平均値を代表値として用いる。

\section{4. 実験結果、分析および考察}

\section{1 啡開放角度と俨閉鎖力}

覀開放角度と閉鎖力の関係を図 6 に示す。扉閉鎖力は、ロードセ ルの位置と屝回転軸との距離 $(0.692 \mathrm{~m})$ を集中荷重に乗じて求めた。

図6より、扉開放角度 $\theta$ の增大に対し、バネ巻数 $I$ に依らず、屝 閉鎖力 $M$ はほぼ同じ傾きで上昇している。図の直線は、各バネ巻数 共に同じ傾きとした回㷌直線である。回帰直線と実験值の相関性は 高い。また、バネ巻数の增加によって扉閉鎖力は、ほぼ等間原で増 大している。従って、屝開放角度と扉閉鎖力の関係は、扉閉鎖時の バネ巻数毎の扉閉鎖力をまとめて $M_{o, i}$ で表すと、式 (2) となる。

$M=0.165 \theta+M_{0, i}$

図 7 は、式 (2) の $M_{o, i}$ とバネ巻数の関係を示したものである。屝 閉鎖時の覀閉鎖力である $M_{o, i}$ とバネ巻数には、非常に高い相関性が あることがわかる。この回帰直線は、式 (3)で表せる。

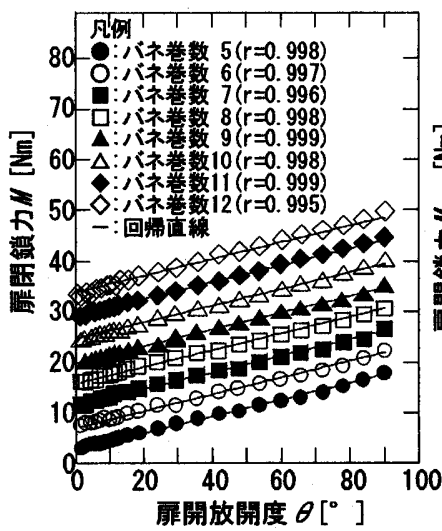

図 6 扉開放角度と扉閉鎖力

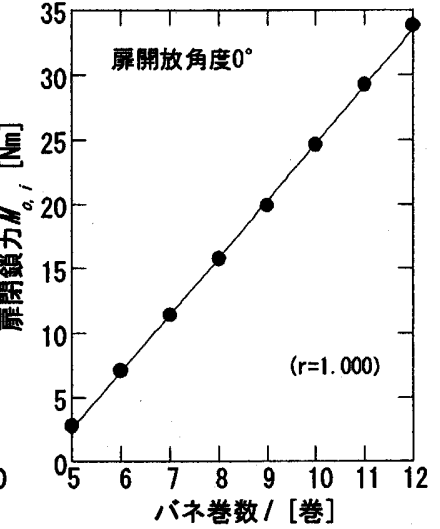

図 7 バネ巻数と扉閉鎖力
$M_{o, t}=4.43 I-19.58(5 \leq I \leq 12)$

以上のことから、標準的なバネの巻数に対する秒閉鎖力が把握さ れた。式 (2)、（3）を用い、閉鎖力の推定が可能と考えられる。

\section{2 啡開放角度と流量保数}

中間的開放角度の扉について流量係数 $\alpha$ を捉える。

扉開放部分を単純開口と仮定し、計測した扉開放角度 $\theta$ について $(2 \rho \Delta P)^{0.5}$ に対する㗺通過風量を図 8 に示す。式（1）を基本とし、

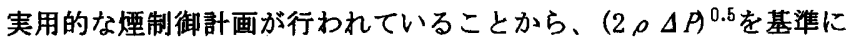
整理した。 $\Delta P$ は、廊下 1 と燃焼空間との閒にある 4 点の室間圧力 差の平均值である。屝通過風量は排煙空間と燃焼空間を一体の空間 とし、この一体とした空間へ陌間を通して流入する流量を機械排煙

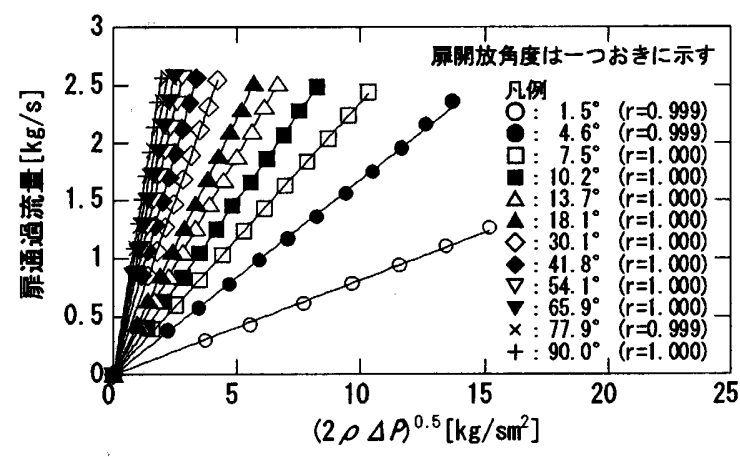

（a）扉の開放方向と屝通過気流の流れが同方向の場合

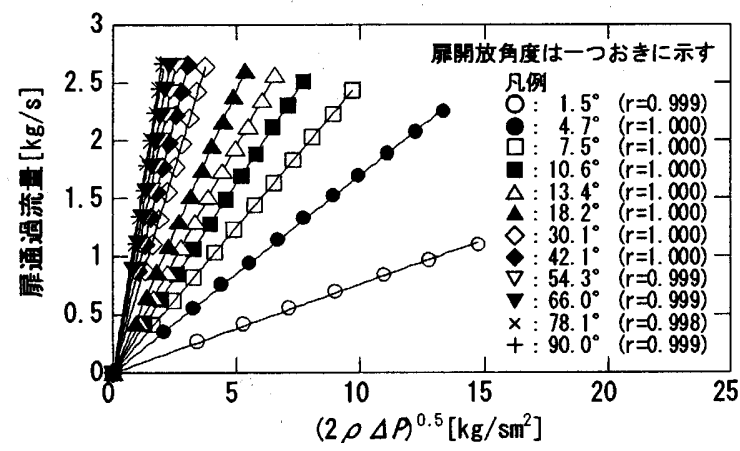

（b）扉の開放方向と扉通過気流の流れが逆方向の場合

図 $8(2 \rho \Delta P)^{0.5}$ と扉通過風量 
風量から差し引いたものとした。排煙空間および燃焼空間迴りの主 な隙間相当開口面積の大きさは、赛測で得られた表 3 の実測値を用 いている。図中の直線は、プロットした点毎の回帰直線である。

図8 から、屝開放角度毎にみて、プロットした点と回帰直線との 相関性は高いことがわかる。これより、 $(2 \rho \Delta P)^{0.5}$ と扉通過風量 の関係は直線近似できる。傾きが有効開口面積 $\alpha A$ である。

図 9 には、呇開放角度に対する流量係数 $\alpha(=\alpha A / A)$ を示す。有効 開口面糟 $\alpha A$ は、防火扉の隙間相当開口面積 $0.012 \mathrm{~m}^{2}$ を差し引いた ものである。隙閒相当開口面積を除いた閉鎖時の流量保数は零とし た。また、開口形状が類似しているはね出し空の値 ${ }^{7}$ 、および屝全 開時の流量係数に今回の実験值を用いて自然排煙公の有効面樌を求 める方法 ${ }^{8)}$ を適用した流量係数の算定值も併せて示す。なお、屝面 積 $A$ は、開放端側から回転軸までの長さ $(0.765 \mathrm{~m})$ をとり、これと屝 高さを乗じたものとした。 $\alpha A$ を基準にすると、実用上で覀幅を用 いる場合は図の $\alpha$ を $0.96(=0.765 \mathrm{~m} / 0.8 \mathrm{~m})$ 倍、あるいは、全開時の開 口幅を用いる場合は $1.08(=0.765 \mathrm{~m} / 0.7 \mathrm{~lm})$ 倍の調整が考えられる。

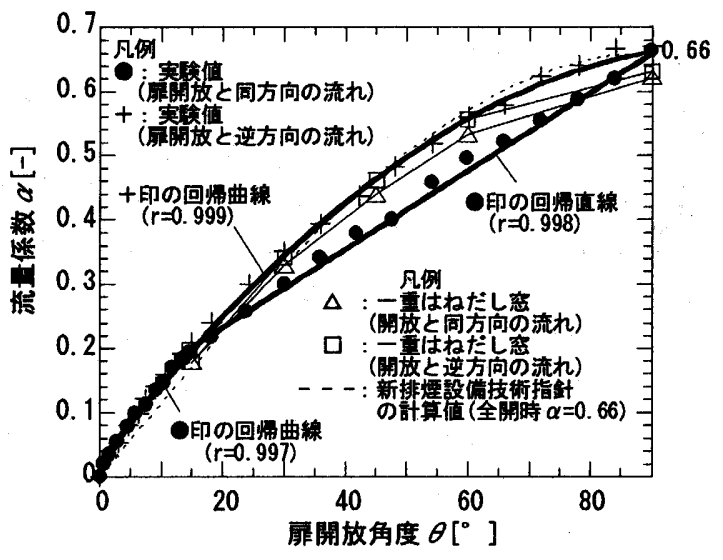

図 9 扉開放角度と流量係数

図 9 をみると、韲の開放方向が扉通過気流の流れと同方向の場合 防火扉の流量係数は、扉開放角度が約 $20^{\circ} \sim$ 約 $80^{\circ}$ の範囲内で、は ね出し空および全開時の流量俰数 0.66 から求めた自然排煙空の值よ り小さくなっている。その範囲以外では、防火郝の流量俰数の方が 大きくなる傾向にある。また、苝開放角度の增大に対し、防火㠑の 流量係数は、扉開放角度が $15^{\circ}$ 未満でやや曲線的に、1 $15^{\circ}$ 以上で直 線的に增加している。これらの関係を示す回帰式は式 (4)である。

$\alpha=-0.0003 \theta^{2}+0.017 \theta+0.0071\left(0^{\circ} \leq \theta<15^{\circ}\right)$

$\alpha=0.0061 \theta+0.11\left(15^{\circ} \leq \theta \leq 90^{\circ}\right)$

一方、郝の開放方向が屝通過気流の流れと逆方向の場合、防火屝 の流量係数は、扉開放角度の增大に対し、曲線的に増加しているこ とがわかる。この流量係数は、式 (5) の回㷌式で示される。郝の開 放方向と扉通過気流の流れが同方向の場合と比較すると、流量係数 は、同じ扉開放角度に対し、約 $20^{\circ}$ 近くから大きくなり、その違い が顕著となる。また、開放角度の全体にわたり、はね出し空のもの よりも大きい。全開時の流量係数を 0.66 として求めた自然排煙空の ものに対して、流量係数は、開放角度が約 $45^{\circ}$ より小さいと、大き く、開放角度が約 $45^{\circ}$ を越えると、わずかであるが、小さくなる。 $\alpha=0.023+0.0125 \theta-0.000060 \theta^{2}\left(0^{\circ} \leq \theta \leq 90^{\circ}\right)$

さらに、本実験とやや形状の異なる防火苝で、㠑開放角度を 0 $60^{\circ}$ まで12段階で変えて行われた実験 ${ }^{5)}$ と、本実験による流量係数 は、類似の傾向を示している。数值も大きくは異なっていない。 以上のことから、任意の郝開放角度に対する流量係数の算定には 式 (4)、式 (5) を適用することが可能である。

\section{3 罪開放角度と圧力差分布係数およひ室間圧力差}

悲の回転が固定されず、室間圧力差によって扉が自由に動くよう な場合である。このときの呇開放角度 $\theta$ と室間圧力差 $\Delta P$ の関係を 検討する。室間に温度差がない等圧の場合に関係を把握し、温度差 があり、不等圧となる場合にも関係が成立するかを確認する。

\subsection{1 回転を固定していない屝の挙動の考え方}

回転を固定されていない郝が微少な角度で開放され、室間圧力差

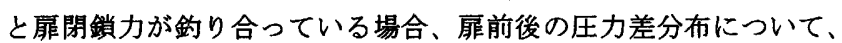
韮開放に関わる圧力差分布の有効篹囲を考え、モデル化する。

図10は、中間的開放状態にある屝 $B$ の前後（図4)の圧力差分布を 表したものである。横軸は、計測点 $J$ を示す。縦軸は、各計測点の 圧力差 $\Delta P_{j}$ を宔閒圧力差 $\Delta P$ で除した値である。

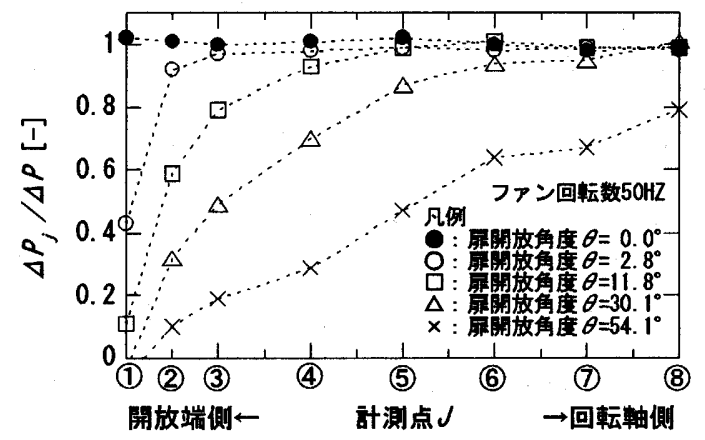

図10 扉 $B$ 前後の圧力差分布

図10から、各計測点の圧力差と室閒圧力差の比 $\Delta P_{j} / \Delta P$ は、扉

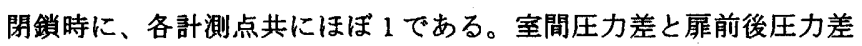
が等しいことがわかる。これに対し、扉が開放されると、開放端側 に近い圧力差の比が 1 より小さくなる。屝開放角度が大きくなるに 従って、压力差の比が 1 より小さくなる範囲が回転軸側に拡大して いることがわかる。このとき、同じ計測点では、圧力差の比の值は より小さくなる方向にある。扉開放角度がさらに增すと、回転軸に 最も近い計測位置の圧力差の比も1より小さくなる。

つまり、中間的開放扉の圧力差分布の大きさは、開放端側に近い ほど、室閒圧力差に対し、低減が著しく、小さなものとなる。

図11は、開放角度 $\theta$ である中間的開放扉の室間圧力差 $\Delta P$ と郝閉 鎖力 $M$ との水平断面での釣合の概念図である。中間的開放罪を通し て1方向に流れがある場合である。室内圧力は水平方向に一様とし ている。室間圧力差 $A P$ は、扉高さ方向の圧力差の平均とする。 中間的開放時には、屝閉鎖時のような屝全体にわたって $\Delta P$ 等 しい圧力差の分布がない（図 10）。中閒的開放の開口を通る流れは 開放された開口の端部側で剥離し、圧力差が生じにくくなる ${ }^{9)} 。-$ 方、煙制御計画に適用する上で室間圧力差 $\Delta P$ を使えると、実用的 
である。これらのことをもとに、圧力差分布を䉮便化した。すなわ ち、図11に示す幅 $a$ の部分まで $\Delta P \cos \theta$ の圧力差が一様に生じるも のとした。この篹囲までの一様な圧力差分布によって扉が開放する ものと仮定する。幅 $a$ の部分を㠑開放に関わる圧力差分布の有効籍 囲とした。この圧力差分布の有效筑囲を無次元化し、 $a /$ とした。 無次元化した有效範囲 $a L$ を圧力差分布係数 $\beta$ とした。

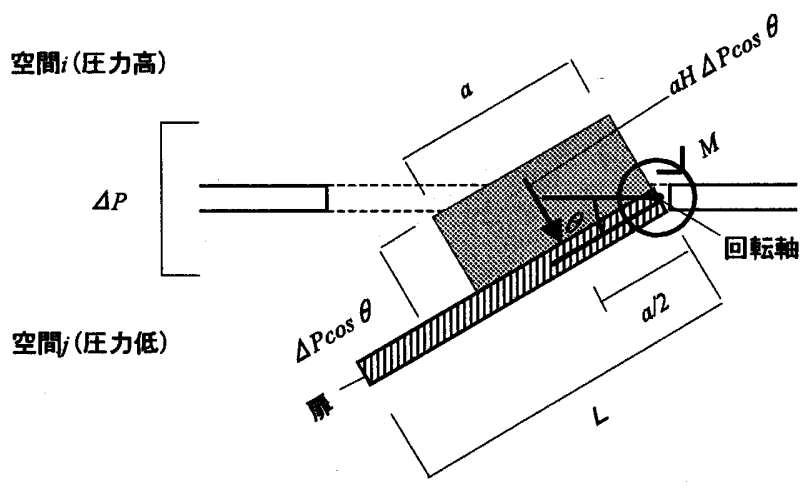

図11中間的開放屝の前後圧力差 $\Delta P \cos \theta$ と閉鎖力 $M$ の釣合の概念

図11より、回転軸におけるモーメントの釣合から式 (6) が得られ る。式 (6) から、压力差分布係数 $\beta$ は式 (7) で表される。

$a H \Delta P \cos \theta \times 1 / 2 a=M$

$\beta=\alpha / L=\sqrt{\frac{2 M / L}{H L \Delta P \cos \theta}}$

\subsection{2 等圧の場合}

\section{（1）覀開放角度と压力差分布係数}

式 (7) は、次式のように変形される。

$\beta=\sqrt{\frac{2}{H L^{2}}} \sqrt{\frac{M}{\Delta P}} \sqrt{\frac{1}{\cos \theta}}$

啡開放角度 $\theta$ と圧力差分布係数 $\beta$ の式 (8) による関係をバネ巻数 $I$ 毎に図12に示す。図中のプロットした点は、扉閉鎖力 $M$ に式 (2) を、廊下 1 と燃焼空間の室間圧力差の平均値（図13のプロット）を $\Delta P$ に用いたものである。

図12から、バネ巻数が多く、扉閉鎖力が大きいと、同じ扉開放角 度に対して圧力差分布係数は大きくなることがわかる。また、圧力 差分布係数は、屝開放角度が約 $6^{\circ}$ まで開放角度の増大に対して、 バネ巻数 5 でやや変動があるが、各バネ巻数共に減少している。一 方、屝開放角度が約 $6^{\circ}$ を越えて增大寸ると、バネ巻数 5 の場合、 圧力差分布係数も增大寸ることがわかる。バネ卷数 6 の場合、圧力 差分布係数は、大きく変動せず、ほぼ一定に近い傾向がみられる。 バネ巻数が 7 以上になると、圧力差分布係数は、減少が緩やかにな り、そのまま減少していく傾向が伺える。

また、屝開鎖力 $M$ のように、屝開放角度 $\theta$ に対して室閒圧力差 $\Delta$ $P$ をプロットしたものが図13である。図中の直線は、扉開放角度の $6^{\circ}$ を境界とし、バネ巻数每に求めた回帰直線である。回帰直線と

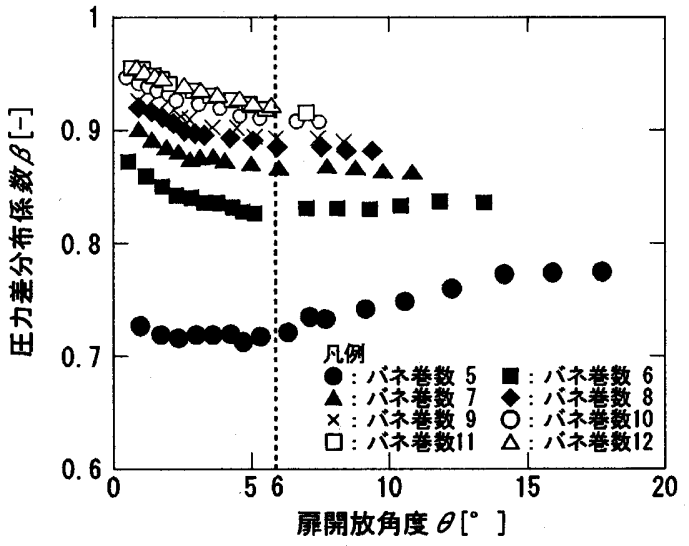

図12 屝開放角度と圧力差分布係数

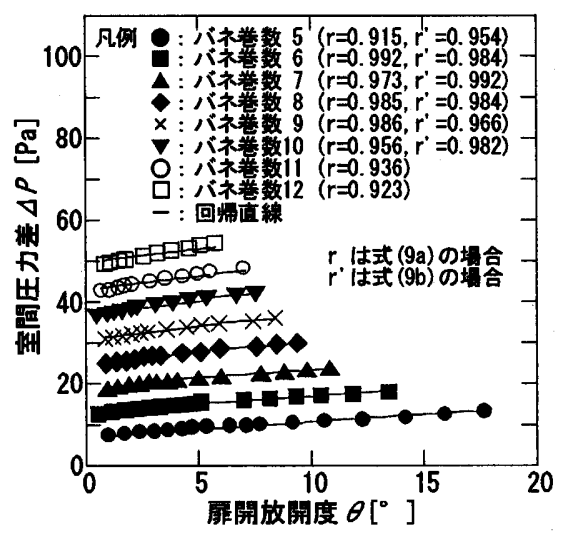

図13 覀開放角度と室閒圧力差

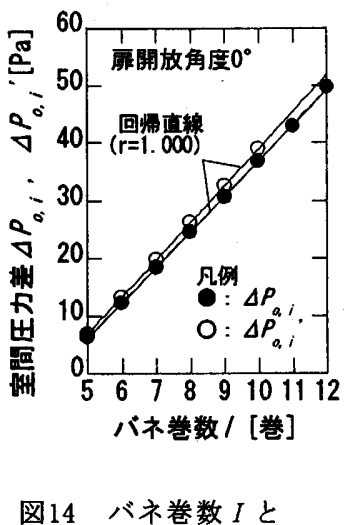

室閒圧力差 $\Delta P_{o, i}, \Delta P_{o, i}$ '
プロットした点との相関性は高いことがわかる。各回帰直線をまと めて、式 (9)に示す。

$$
\begin{aligned}
& \Delta P=0.66 \theta+\Delta P_{o, i}\left(0^{\circ} \leq \theta<6^{\circ}\right) \\
& \Delta P=0.37 \theta+\Delta P_{o, i}\left(6^{\circ} \leq \theta\right)
\end{aligned}
$$

バネ巻数 $I$ に対する室間圧力差 $\Delta P_{o, i}$ と $\Delta P_{o, i}$ を、罒14に整理し た。プロットした $\Delta P_{o, t}$ の点は、式(9a)で、郝開放角度を零と設定 したときのバネ巻数毎の值である。同様に、 $\Delta P_{o, i}$ の点は、式(9b) によるものである。 $\Delta P_{o, i}$ と $\Delta P_{o, l}$, のプロットに対して求めた各回 㛿直線の回帰式は、式(10)である

$\Delta P_{o, i}=6.18 I-24.78\left(5 \leq I \leq 12,0^{\circ} \leq \theta<6^{\circ}\right)$
$\Delta P_{o, i}{ }^{\prime}=6.45 I-25.36\left(5 \leq I \leq 10,6^{\circ} \leq \theta\right)$

このように、本実験では、 $M$ と $\Delta P$ が扉開放角度 $\theta$ の一次式で表 せる。式 (8)の $(M / \Delta P)^{0.5}$ は、 $a_{1}$ を $M 、 a_{2}$ を $\Delta P$ の㑯きとし、 $b_{1}$ を $M 、 b_{2}$ を $\Delta P$ の $\mathrm{y}$ 切片とすると、 $\left\{\left(a_{1} \theta+b_{1}\right) /\left(a_{2} \theta+b_{2}\right)\right\}^{0.5}$ で整 理される。 $\left(a_{1} \theta+b_{1}\right) /\left(a_{2} \theta+b_{2}\right)$ の微分係数を求めると、 $\left(a_{1} b_{2}-a_{2}\right.$ $\left.b_{1}\right) /\left(a_{2} \theta+b_{2}\right)^{2}$ となる。これより、 $(M / \Delta P)^{0.5}$ は、 $a_{1} b_{2}-a_{2} b_{1}$ が正なら単純增加、負なら単純減少となる。そこで、バネ巻数毎に 式 (2)の 0.165 を $a_{1}$ に、式 (3) の $M_{0, i}$ を $b_{1}$ に、悲開放角度 $6^{\circ}$ を境 界に式(9) の0.66あるいは0.37を $a_{2} に 、$ 式(10)の $\Delta P_{o, i}$ あるいは $\Delta$ $P_{o, i}{ }^{\prime}$ を $b_{2}$ に代入した。バネ巻数が 5 で、屝開放角度が $6^{\circ}$ 以上の場 
合に、 $a_{1} b_{2}-a_{2} b_{1}$ が正となり、単純增加する。それ以外は、 $a_{1} b_{2}-$ $a_{2} b_{1}$ の值が負となり、単純珹少の傾向がある。また、 $(1 / \cos \theta)^{0.5}$ の $1 / \cos \theta$ の微分係数は $\sin \theta / \cos ^{2} \theta$ で正となる。 $(1 / \cos \theta)^{0.5}$ は、単純增加するが、 $\theta$ が小さいと、1から大きく增加しない。

これより、バネ巻数 5 で、 $(M / \Delta P)^{0.5}$ が概称純减少から単純 增加に変わる図12にみられる状況が生じたものと考えられる。

図12に示す圧力差分布係数は、無次元量である。屝形状に依らず 扉閉鎖力毎に扉開放角度に応じて用いることが可能と推察される。

（2）啡形状が異なる場合の室間圧力差の推定

異なる形状で同じ閉鎖力 $M$ を有している二つの乍が同じ扉開放角 度 $\theta$ だけ開放されている場合、二つの圧力差分布俰数の関倸から室 間圧力差の関係を捉える。圧力差分布係数を $\beta 、 \beta$ 'とする。 式(11)より、 $\beta^{\prime} を \beta$ で除したものは、以下のように表される。

$\beta^{\prime} / \beta=\sqrt{\frac{2 M / L^{\prime}}{H^{\prime} L^{\prime} \Delta P^{\prime} \cos \theta}} \times \sqrt{\frac{H L \Delta P \cos \theta}{2 M / L}}=\sqrt{\frac{H L \Delta P \times L / 2}{H^{\prime} L^{\prime} \Delta P^{\prime} \times L^{\prime} / 2}}$

$H L \Delta P \times L / 2$ は、覀閉鎖時に、䪞の重心にかかる圧力差により生 じる郝開放力である。これは、扉開放前の郝閉鎖力 $M_{0}$ に等しい。 $H^{\prime} L^{\prime} \Delta P^{\prime} \times L L^{\prime} / 2$ も同様である。更に、ここでは、 $M_{0}$ と $M_{o}^{\prime}$ が等し い。したがって、式(11)は式(12)のように整理される。これより、 扉閉鎖力が同じ場合に、圧力差分布係数は、郝形状に依らず、同じ 覀開放角度に対して同じ値をとることが確認される。

$\beta^{\prime} \beta=\sqrt{\frac{H L \Delta P \times L / 2}{H^{\prime} L^{\prime} \Delta P^{\prime} \times L^{\prime} / 2}}=\sqrt{\frac{M_{0}}{M_{0}^{\prime}}}=1$

室間圧力差について式(12)を整理し、式(13)が得られる。

$\Delta P^{\prime}=\Delta P \frac{H L^{2}}{H^{\prime} L^{\prime 2}}$

式(13)から、形状の異なる扉の室間圧力差 $\Delta P^{\prime}$ 、同じ尿開放角 度に対し、推定することが可能となる。すなわち、㗺開放角度と室 閒圧力差 $\Delta P$ との関倸を、特定の屝で捉えておくことにより、任意 の形状の扉についても、式(13)を適用し、扉開放角度と室間圧力差 $\Delta P^{\prime}$ との関倸を具体化することができる。

以上のことから、呇の回転を固定しない場合、形状が異なる扉の 扉開放角度と室間圧力差の関係は、式 (9)、(13)から求められる。

\subsection{3 不等圧の場合}

燃焼に伴う温度差が扉前後にあり、室間圧力差が不等圧となって いる場合にも、屝の回転を固定しない状態で、式 (7) で示される基 本関保が成立するか否かを把握する。

図15には、扉の回転を固定していない燃焼実験ケースについて、 室間圧力差 P1 および燃焼空間の温度 T2 の時間変化を示す。

図をみると、室間圧力差が着火後に大きく変化を始めている。す なわち、最上部の室間圧力差は、温度上昇に伴い、徐々に低下して いる。これに対し、最下部の室間圧力差は、着火直後に増加し、そ の後、ほぼ一定で推移している。これより、扉の高さ方向には、圧

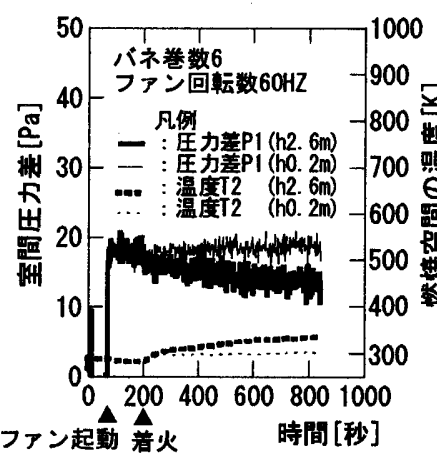

(a) 実験ケース 4-1

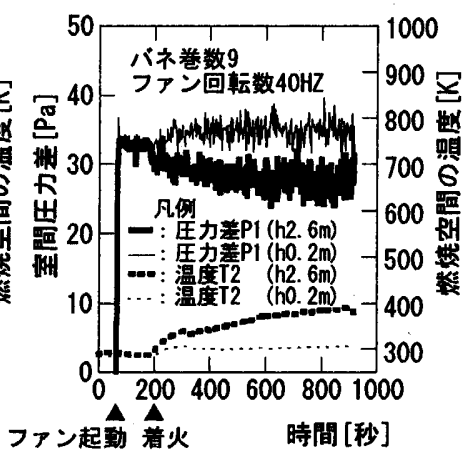

(b) 実験ケース 4-2

図15 高さ別の室間圧力差と空間温度の時間変化

$$
\Delta P=\frac{2 M / L}{\beta^{2} H L \cos \theta}
$$

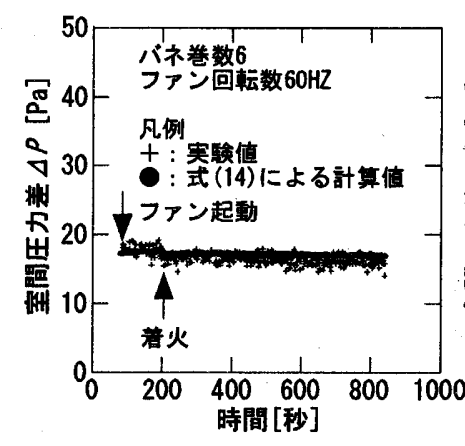

(a) 実験ケース 4-1

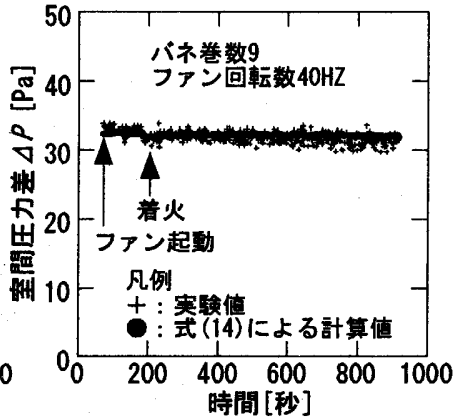

(b) 実験ケース 4-2
図16 室間圧力差の比較 (不等圧の場合)

力差が確認される。なお、室間圧力差は最上部でも零を下回らず、 廊下 1 側から燃焼空間へ 1 方向の流れが維持されている。

このように、燃焼空間の温度上昇によって室間圧力差が不等圧に ある状況で、式 (7) による室間圧力差の計算值と実験值を比較し、 式 (7) の適用性を検討した。計算値は、式 (7) を変形した式(14)に よって求めた。式 (2)による扉閉鎖力 $M$ を、および図12による圧力 差分布俰数 $\beta$ の值をもとに実験ケース 4-1、実験ケース 4-2 の丞開 放角度 $\theta$ に対応させて補間して求めた $\beta$ を式(14)に与えた。式(14) による室間圧力差の計算値は平均値である。赛験值も、高さ方向に ある 4 点の室間圧力差の平均値である。室間圧力差の計算值と実験 值を図16に示す。実験値には多少の変動がみられるが、計算值と実 験値は概ね一致していることが伺える。

これより、室間圧力差が不等圧の場合も、中閒的開放扉の開放角 度に対する圧力差分布俰数 $\beta$ は適用可能であることが確認される。 室間温度差が大きくなり、不等圧が変化しても、屝通過の流れが 1 方向の場合には、式(14)の関係を適用できるものと考えられる。

\section{4 扉開放直前の室間圧力美}

回転が固定でない扉の開放直前の圧力差に関わる要素を捉える。 実験タイプ 3 の各ケースの扉通過風量と室閒圧力差の関係を図 17 に示す。屝通過風量は一体空間迴りの隙間（表3）の流入量をダクト 風量から引いたものである。図の実線は式 (10a) の $\Delta P_{o, i}$ を示す。 
室間圧力差は、図17より、各バネ巻数ともに、㗺が開放される直 前まで扉通過風量の增加に伴い、ほぼ一直線上を上昇している。そ の後に、室間圧力差の增大が急激に緩やかになる。これは、扉開放 の開始点である。開始点の室間圧力差は、各バネ巻数ともに巻数に 忘じた $\Delta P_{o, i}$ とほぼ一致することがわかる。

$\Delta P_{o, i}$ を求めるための $M_{o, i}$ との関係を式(15)に表す。式中の $M_{o, i}$ は式 (3)によるものである。郝閉鎖時に圧力を受ける部分を $A$ と する。図18に、実测值とみなせる式 (10a) による $\Delta P_{o, i}$ と式(15)に よる $\Delta P_{o, 1}$ を示す。両者はほぼ一致していることが図よりわかる。

扉仕様の $M_{o, i}$ がわかると、压力が加わる狮面を適切に設定するこ とによって、式(15)を適用し、 $\Delta P_{0, i}$ の推定が可能となる。
$\Delta P_{o, i}=\frac{M_{o, i}}{A^{\prime \prime} L^{\prime \prime}}$

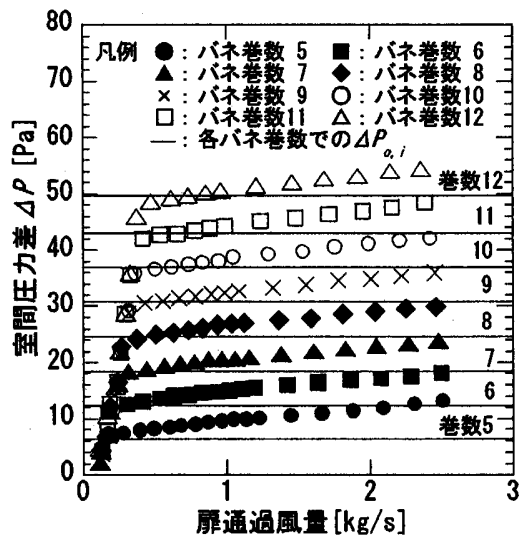

図17 覀開放直前の圧力差

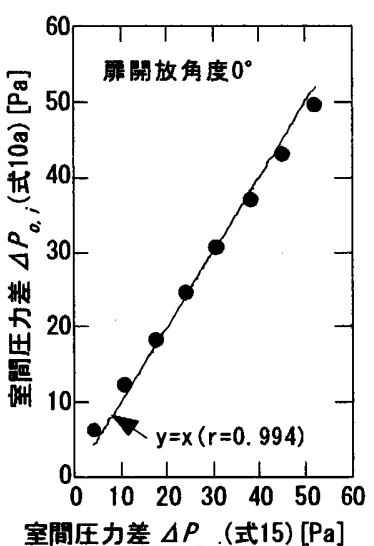

室間圧力差 $\Delta P_{o, i}$ (式15) [Pa]

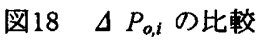

5. おわりに

煙制御計画で室間圧力差の予測に必要な中間的開放扉を用いた実 験を行い、基本特性について以下の点を明らかにした。

・中間的開放㦄開放角度に対する流量係数は、式 (4)、（5）を適 用し、求められる。

- 回転を固定していない扉の開放角度に対する扉閉鎖力、形状、室 間圧力差の関保を式 (7) の圧力差分布係数を導入し、提案した。 圧力差分布係数を適用し、一例であるが、圧力差分布保数の妥当 性を確認した（図 16）。

・回転を固定していない屝について、屝閉鎖力が同じで屝形状が異 なる場合、任意の扉の開放角度と室閒圧力差の関倸は、この関係 を特定の㠑で求めておくことにより、二つの扉の扉幅と高さをも とに式(13)より推定可能である。

- 固定していない扉について、圧力差分布係数を考慮した式(14)に よる室間圧力差の平均の算定は、郝を通過する流れが一方向で、 扉高さ方向に圧力差がある不等圧の場合も適用性が確認された。 ・扉開放直前の室間圧力差は、扉開鎖力の大きさに関わらず、圧力 が作用している扉面積と閉鎖力から式(15)で推定可能である。

今後は、回転を固定していない扉についても、中間的開放角度が 大きい場合、また扉高さ方向の圧力差分布による流れが一方向でな い場合に、基本特性を明らかにする。
記号（凡例）

$A$

A"

h

$H, H^{\prime}$

$I$

$J$

$L, L^{\prime}$

$L "$

$M$

$M_{o} 、 M_{0}{ }^{\prime}$

$M_{o, i}$

$\Delta P, \Delta P$

$\Delta P_{o, i}, \Delta P_{o, i}$

$\Delta P_{J}$

$Q$

r、 r'

$\alpha$

$\beta, \beta^{\prime}$

$\theta$

$\rho$

注）中間的開放屝の流量係数の部分は、屝の開放方向と屝通過気流 の流れが同方向の場合の流量係数に関する報告 ${ }^{B)}$ に、加筆した ものである。

\section{参考文献}

1) Nakaya, I. 、Tanaka, T. and Yoshida, M. : Doorway Flow Induced by a Propane Fire 、Fire Safety Journal 、 Vol. 10、 pp. 185-195 、1986

2）建設省大臣官房技術調查室監修：建筑物の総合防火設計法の開 発 第 1 巻 総合防火設計法、平成元年 4 月

3）金谷靖、高野巷輔、久次米真美子、松下敬幸、田中哮義：事務 所ビルの付室加圧煙制御システムにおける給気量の算定方法（ その 2 平均压力差を用いた流量の計算)、日本建笔学会大会 学術演梗概集 A-2、pp. 165-166、1998年 9 月

4）山名俊男：防火屝開閉装圈の力に関する実験、日本建築学会大 会学術講演梗概集 A、pp. 963-964、1990年10月

5）阿部伸之、川村成产、山田茂、山田常圭：加圧排煙時の消防活 動における郝の流量係数及び開放力に関する実験研究、日本火 災学会研究発表会概要集、pp. 262-265、2004 年 5 月

6）広由正之、山名优男：加圧防煙計画のための水平避難用防火奜 の基本的特性、日本建築学会大会学術講演梗概集 $A-2$ 、 pp. 159-160、1999年 9 月

7) 日本建築学会編：建築資料集成 1 墂境、1978年 6 月

8）建設省住宅局指迸課監修：新・排煙設满技術指針 1987 年版、平 成元年 5 月

9) 有田正光：流れの科学、東京電機大学出版局、1998 